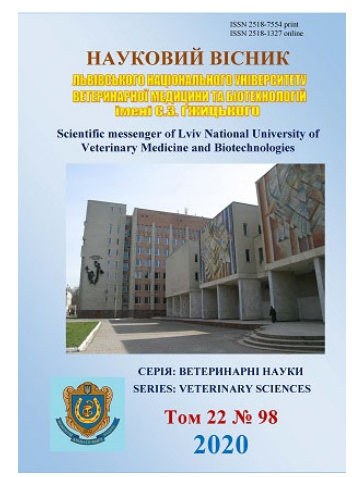

\author{
Науковий вісник Яьвівського націонадьного університету \\ ветеринарної медицини та біотехнологій імені С.3. Гжицького. \\ Серія: Ветеринарні науки \\ Scientific Messenger of Lviv National University \\ of Veterinary Medicine and Biotechnologies. \\ Series: Veterinary sciences
}

UDC 619:616 - 089.8:636.7.082.34

\title{
Comparison of the flank and ventral midline approach for ovariohysterectomy in bitches
}

\author{
A. D. Stepanov
}

State Agrarian and Engineering University in Podilya, Kamianets-Podilskyi, Ukraine

Article info

Received 20.03.2020

Received in revised form 24.04.2020

Accepted 25.04.2020

State Agrarian and Engeneering University in Podilya,

Schevthenko Str., 13, Kamianets-

Podilskyi, 32300, Ukraine.

Tel: +38-098-566-47-94

E-mail: astepanov69@ukr.net
Stepanov, A. D. (2020). Comparison of the flank and ventral midline approach for ovariohysterectomy in bitches. Scientific Messenger of Lviv National University of Veterinary Medicine and Biotechnologies. Series: Veterinary sciences, 22(98), 63-68. doi: 10.32718/nvlvet9811

Surgical access for ovariohysterectomy in bitches through the right lateral abdominal wall with an incision in its upper third in the direction from the anterior edge of the macula to the fourth nipple of the corresponding side of the breast is proposed. The article presents the results of studies obtained when used for the purpose of ovariohysterectomy in bitches of operative access through the right lateral and ventral abdominal wall. Research work was conducted on healthy mature bitches. The operations were performed in the area of the right lateral abdominal wall and in the umbilical region. On the lateral abdominal wall, an oblique-vertical incision was used at the border of the inguinal and iliac areas in the direction from the anterior edge of the macula to the fourth nipple of the corresponding side of the breast. The ventral abdominal wall was cut along the white line. It was found that when performing ovariohysterectomy in bitches using the proposed surgical access through the right lateral abdominal wall with a smaller wound size $(P<0.05)$, the duration of the operation and the healing period correspond to those when using median laparotomy. It is proved that operative access with oblique-vertical incision in the area of the right lateral abdominal wall at the border of the groin and anus during ovariohysterectomy in bitches provides favorable opportunities for surgical reception and closure of the surgical wound. The number of surgical sutures for sutures on the abdominal wall is less than in the case of ventral access $(P<0.01)$. It is also noted that in ovariohysterectomy in bitches, operative access through the right lateral abdominal wall with an incision in the direction from the anterior edge of the macula to the fourth nipple of the corresponding side of the breast may be recommended as an alternative access through the white line of the abdomen.

Key words: dogs, castration of bitches, right flank laparotomy, midline laparotomy, lateral flank approach.

\section{Порівняння бокового $\mathbf{T a}$ вентрального медіанного доступу овірогістеректомії у сук} $3 \mathbf{a}$

\author{
О. Д. Степанов
}

Подільський державний аграрно-технічний університет, м. Кам'янець-Подільський, Україна 
ний доступ з косо-вертикальним розрізом у ділянці правої бокової черевної стінки на межі пахвини $і$ здухвини при оваріогістеректомії у сук забезпечує сприятливі можливості для виконання оперативного прийому та закриття операційної рани. При цьому кількість хірургічних ниток для швів на черевну стінку мениа, ніж у разі вентрального доступу (P < 0,01). Також відмічено, цчо при оваріогістеректомії у сук оперативний доступ через праву бокову черевну стінку з розрізом у напрямку від переднього краю маклока до четвертого соска відповідного боку молочної залози може бути рекомендований як альтернатива доступу через білу лінію живота.

Ключові слова: собаки, кастрація сук, правобічна лапаротомія, медіанна лапаротомія, латеральний доступ.

\section{Introduction}

Bitches are most often castrated to prevent unwanted pregnancies as well as changes in heat-related behavior (Smith \& Séguin, 2012). Epidemiologists and parasitologists are interested in controlling the dog population because they can be a source of more than sixty zoonotic diseases (Kutzler \& Wood, 2006; Rhindali et al., 2006). Pre-intestinal parasites in dogs pose a serious threat to human health (Zanzani et al., 2014).

In bitches, castration can be performed using ovarioectomy or ovariohysterectomy. In veterinary practice, ovariohysterectomy is the most common abdominal surgery in bitches (Howe, 2006).

Removal of the uterus from the ovaries is also indicated for tumors of the uterus (Bencharif et al., 2010), breast (Murai et al., 2012), vaginal prolapse, pyometra, post-estrus metritis (Nakamura et al., 2012). Ovariohysterectomy also minimizes the symptoms associated with diabetes (Pöppl et al., 2013).

Ovariohysterectomy in bitches is performed through an incision of the ventral (DeTora \& McCarthy, 2011), or lateral abdominal wall (Howe, 2006; Bushby \& White, 2019), or by laparoscopy (Freeman \& MacFarlane, 2007).

The ventral wall of the abdomen in ovariohysterectomy in bitches is cut using a median laparotomy (Bierbrier \& Causanschi, 2018) or using paramedian incisions (Quessada et al., 2009).
When using lateral access, bitches can be placed in the left or right lateral position, depending on the preferences of the surgeon. According to McGrath et al., 2004, rightsided access is considered by some surgeons to be more convenient because of the more cranially located right ovary and due to the fact that when accessed from the left, the omentum covers the viscera. However, in their view, there are no advantages of right-hand access over lefthand access.

Despite the fact that lateral access for castration of bitches has been proposed for a long time, it has not become widespread as ventral. Although in some conditions the performance of ovariohysterectomy in bitches is shown only through the lateral abdominal wall. This applies to the overdevelopment of the breast in lactating females or in connection with breast hyperplasia (McGrath et al., 2004).

Less use of lateral access for ovariohysterectomy in bitches is apparently due to the lack of specific information about the location of the skin incision, as well as the difficulties associated with the operation. Different authors report different types of incisions: vertical in the middle between the macula and the last rib (Acharya et al., 2016); oblique ventro-caudal lead, retreating to a width of two or three fingers behind the last rib, ventrally from the transverse processes of the lumbar vertebrae (Arunkumar et al., 2017); oblique ventro-caudal in the middle of the auricle (Vandana, 2005) (Fig. 1).

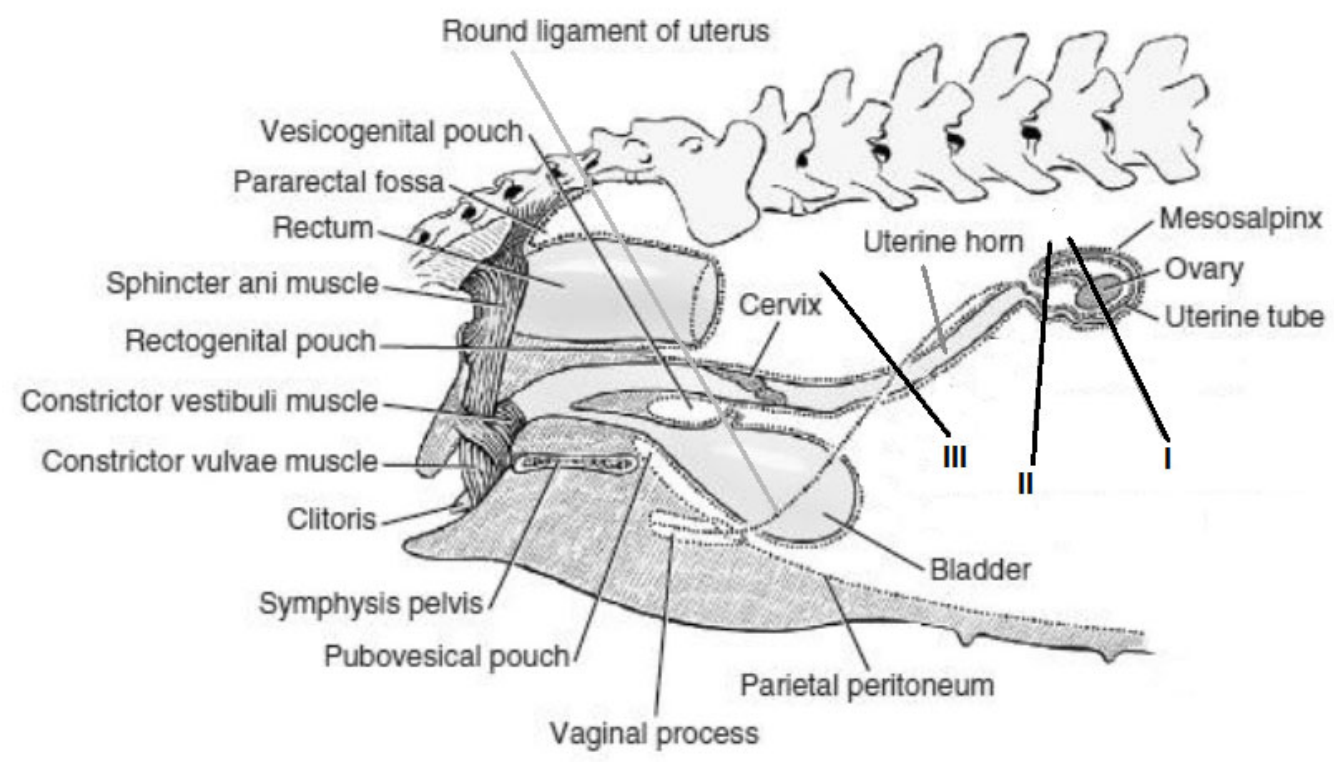

Fig. 1. The location of the genitals in bitches according to Evans \& De Lahunta, 2013, with incisions of the lateral abdominal wall: I - vertical in the middle of the abdomen; II - ventro-caudal in the middle of the iliac; III - obliquely vertical on the border of the groin and anus in the direction from the anterior edge of the macula to the fourth nipple of the corresponding side of the breast 
However, the experience of using incisions through the middle of the abdomen in bitches has shown that they do not provide the conditions for the imposition of a ligature on the body of the uterus, especially in animals with a long body. Our data are consistent with those obtained by McGrath et al., 2004, who reported that such incisions do not promote uterine imaging.

The difficulty of performing ovariohysterectomy in bitches through an incision in the middle of the iliac has an anatomical explanation. The cervix lies a few centimeters in front of the anterior border of the pubis and together with the body of the uterus have a length of 4-7 cm (Bencharif et al., 2010). This means that the farther from this level the incision is made, the more difficult it is to perform surgery on the uterus (Fig. 1).

To eliminate these shortcomings associated with lateral access in ovariohysterectomy in bitches, we proposed an oblique vertical incision in the upper third of the right lateral abdominal wall in the direction from the anterior edge of the macula to the fourth nipple of the corresponding side of the breast (Fig. 1, III).

The aim of the study was to give a comparative assessment of two methods of performing ovariohysterectomy in bitches: through the right lateral abdominal wall and the white line of the abdomen.

\section{Material and research methods}

The work was performed in the clinic of the Faculty of Veterinary Medicine of Podilsk State Agrarian Technical University. The ovaries were removed in healthy nonpregnant bitches over 12 months of age, with an average weight of $14.4 \pm 5.4 \mathrm{~kg}$, outbred and in two shepherds. In order to conduct the experiment, two experimental groups were formed: I and II. In each of the groups, animals were selected on the principle of analogues, which were similar in weight and body size. Group I bitches underwent ovariohysterectomy through an incision along the white line of the abdomen, in group II used surgical access through the right lateral abdominal wall.

Prior to surgery, the animals were kept on a 12-hour fasting diet. In order premedication was administered subcutaneously $0.1 \%$ solution of atropine sulfate $0.05 \mathrm{mg} / \mathrm{kg}$ intramuscularly and $2 \%$ xylazine solution at a dose of $0.15 \mathrm{ml} / \mathrm{kg}$. For the purpose of anesthesia intravenously into the subcutaneous vein of the forearm was injected zoletil 100 at a dose of $15 \mathrm{mg} / \mathrm{kg}$. After closing the abdominal wall, amoxicillin $15 \%$ was injected subcutaneously at a dose of $0.1 \mathrm{ml} / \mathrm{kg}$. Re-injection of $15 \%$ amoxicillin at the same dose was performed 48 hours after surgery.

Polyglactin 2-0 was used as a suture material for ligatures on the ovaries and uterus, and polyamide 2-0 was used to suture the white line, abdominal muscles, and skin.

In each case, the size of the surgical wound, the amount of suture material used, the duration of the operation were recorded, and the healing of surgical wounds was observed.

The duration of the intervention was taken from the beginning of the incision to the end of suturing the skin wound. The condition of postoperative wounds was monitored by external observation.

After performing general anesthesia, the animal was fixed. During the median laparotomy, the animal was fixed in the dorsal position, if the operation was performed through the lateral abdominal wall - in the left lateral position with the pelvic limbs set back.

When performing ovariohysterectomy in bitches using median laparotomy in the umbilical region, the operation was performed in the traditional way with the imposition of ligatures on the ovarian ligaments and uterus, furrier suture on the white line and nodal sutures on the skin (Bencharif et al., 2010).

Performing the operation through the right lateral abdominal wall, the incision was made in the upper third of the abdomen and was made on the border between the inguinal and iliac areas along the line from the anterior edge of the macula towards the fourth nipple of the corresponding side of the breast (Fig. 2).

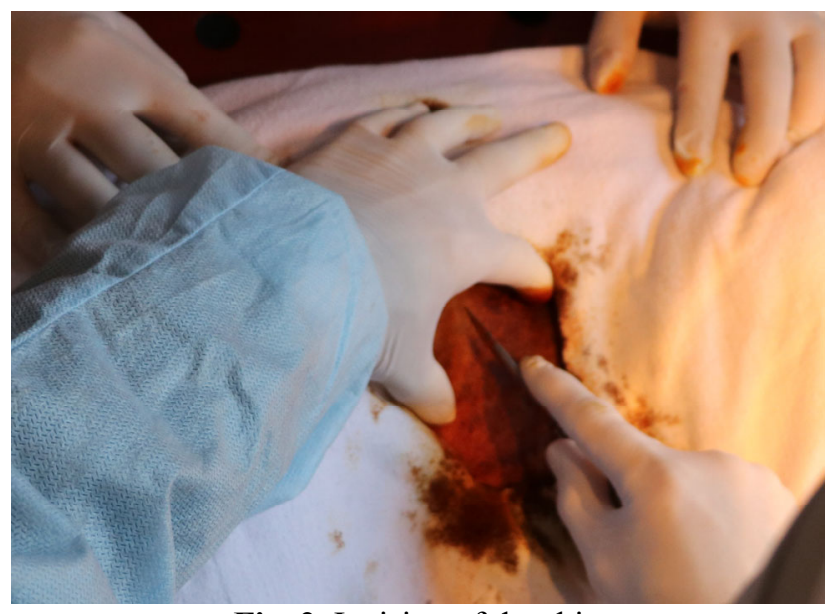

Fig. 2. Incision of the skin

A piece of subcutaneous fat was then cut with scissors, exposing the external oblique abdominal muscle in the wound. Using small hemostatic forceps with thin branches in the center of the wound, the abdominal muscles were gently pierced along with the peritoneum. By diluting the branches of the clamp increased the hole in the abdominal cavity (Fig. 3).

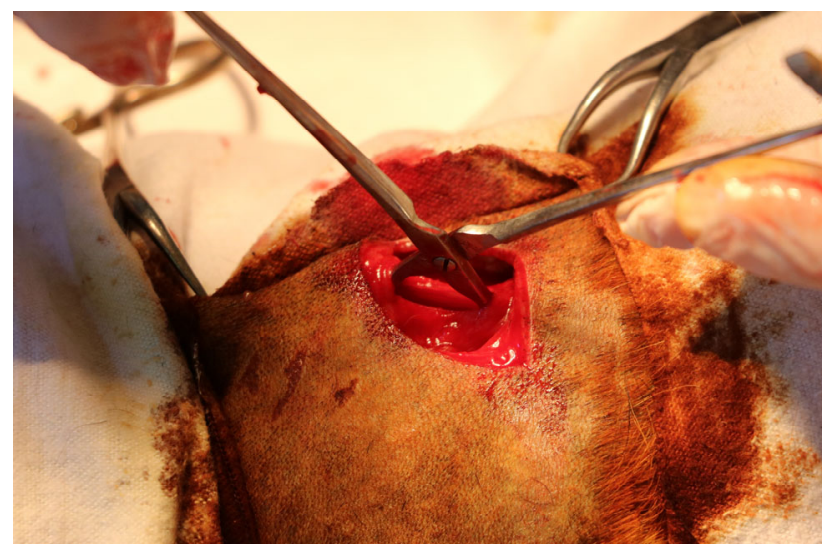

Fig. 3. Separation of the abdominal wall in a blunt manner 
In large bitches, the muscles were pierced with the tip of a scalpel handle without a blade, after which the hole between the muscles was enlarged in a blunt manner. The hole in the peritoneum was made with sharp scissors. Wound hooks stretched the edges of the wound (Fig. 4).

A castration hook was inserted into the wound, which was used to grasp and pull out the right uterine horn with the ovary (Fig. 5).

After ovariohysterectomy, several sutures of the nodal suture were applied separately to the internal and external oblique abdominal muscles, as well as nodular stitches to the skin.

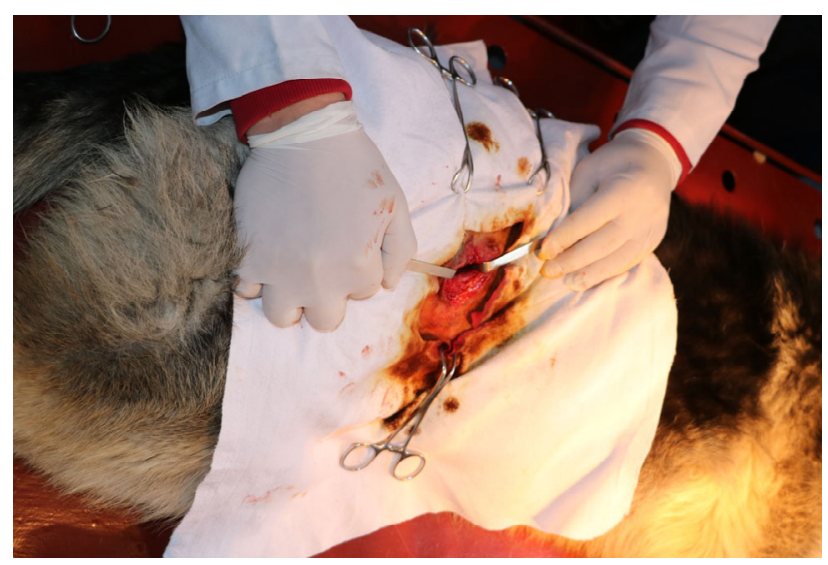

Fig. 4. Dilution of wound edges with wound hooks

\section{Results and discussion}

When performing ovariohysterectomy in bitches using median laparotomy, the skin incision was started at a distance of $2 \mathrm{~cm}$ from the navel and continued caudally for a length of about $4 \mathrm{~cm}$, after which it was increased cranially or caudally during surgery. The average length of the surgical wound in bitches who underwent median laparotomy was $5.51 \pm 0.78 \mathrm{~cm}$.

All operations were performed successfully, however, we observed some difficulties: the detection of ovaries in bitches that did not give birth required additional time.

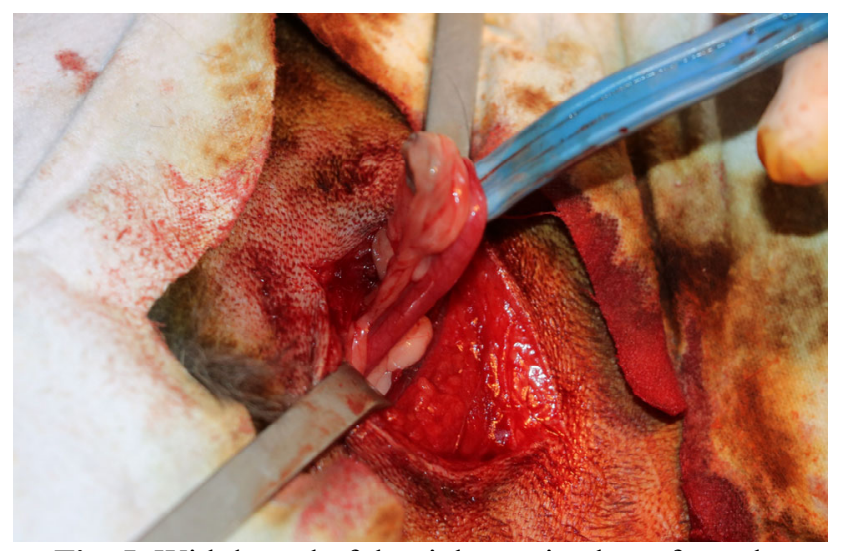

Fig. 5. Withdrawal of the right uterine horn from the wound

Evaluation of the use of suture material to apply ligatures to the ovarian and uterine ligaments for ventral access showed that an average of $15.63 \pm 0.82 \mathrm{~cm}$ of $2-0$ polyglactin was used. However, for suturing the abdominal wall on each animal on average used $50.67 \pm 1.64 \mathrm{~cm}$ of polyamide $2-0$.

The operations lasted an average of $41.2 \pm$ 2.36 minutes

In the postoperative period, all operated on through the incision along the white line of the bitch wounds healed without complications. The general condition of the animals during the first three days after surgery was characterized by depression, they mostly lay down.

Performing a laparotomy in the area of the right lateral abdominal wall, in its upper third was a oblique incision of the skin length of $3.43 \pm 0.44 \mathrm{~cm}$.

A characteristic feature of the operations was a fairly easy laparotomy, search for uterine horns and closing the wound of the abdominal wall.

In addition, when using access through the lateral abdominal wall, the position of the wound provided favorable conditions for the imposition of ligatures on the ovarian ligament at a sufficient distance from the ovary (Fig. 6). In four animals, there was no need to predisconnect the supporting ligament, the same number disconnected the supporting ligament of the left and right ovaries, and two - only the left ovary.

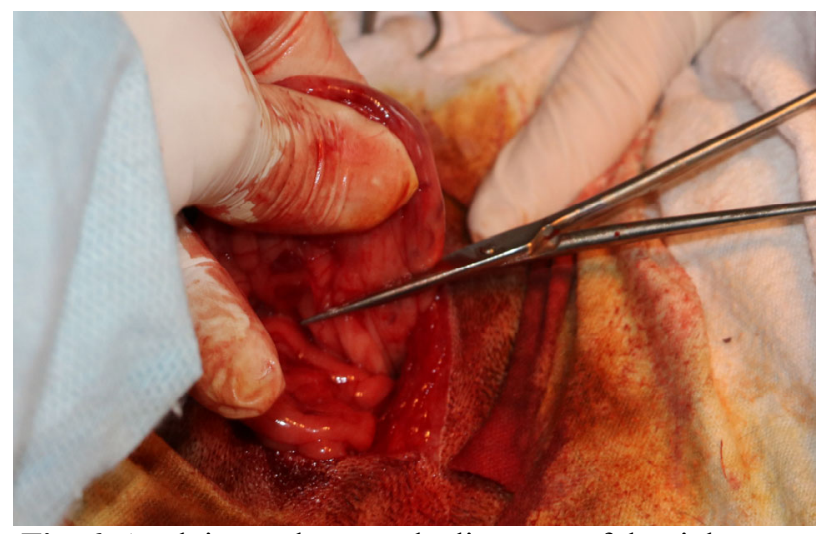

Fig. 6. Applying a clamp to the ligament of the right ovary

Due to the convenient location of the wound opening, such an important stage of the operation as the removal of the left ovary was performed without complications. For this purpose, the bifurcation of the uterine horns was pulled into the wound and passed to the left horn (Fig. 7).

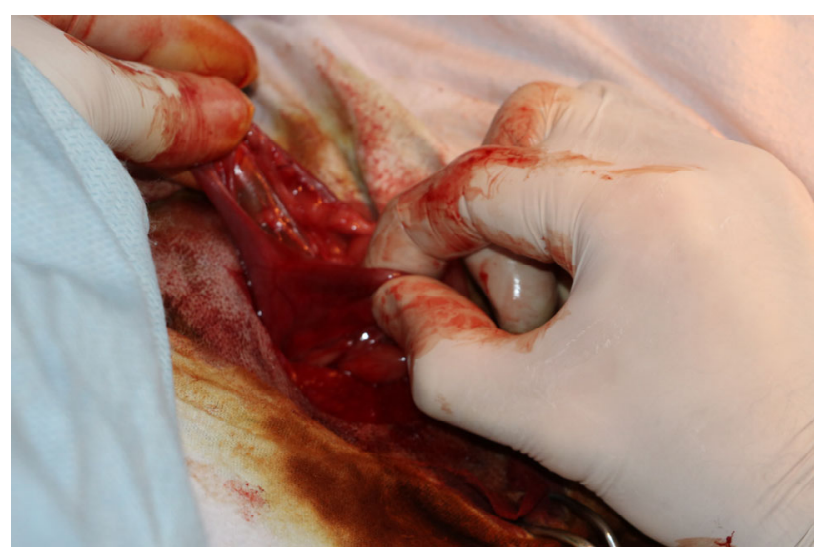

Fig. 7. The site of bifurcation of the uterine horns 
Similarly, it was quite convenient to impose a ligature on the body of the uterus. This did not require an increase in wound size. When the uterus was slightly stretched, a piercing ligature was performed in the area of her body (Fig. 8).

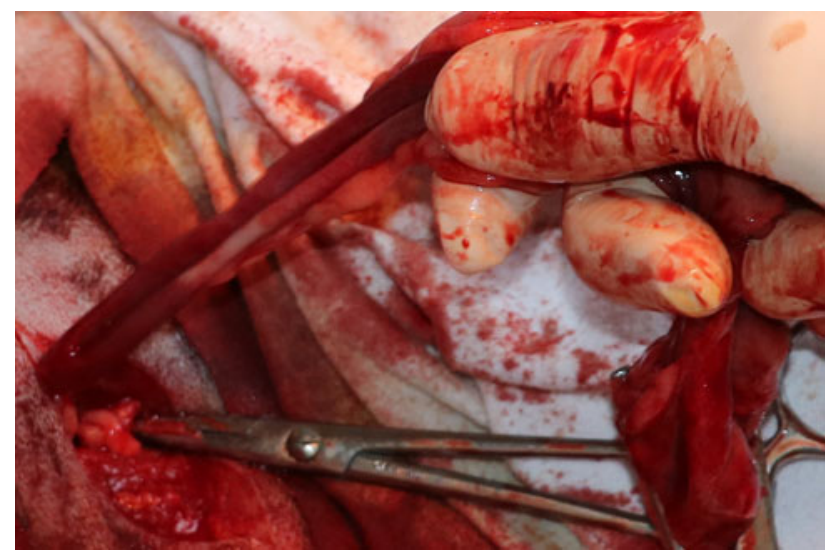

Fig. 8. Imposition of a ligature on the body of the uterus

The length of the strands of polyglactin 2-0, applied to the ovarian ligaments and uterus in lateral access, per animal was $16.12 \pm 0.67 \mathrm{~cm}$, while to close the wound of the abdominal wall used $45.25 \pm 0.69 \mathrm{~cm}$ polyamide $2-0$.

The operations lasted an average of $35.5 \pm 1.58$ minutes.

The animals ate from the second day after castration, and three days later their condition was almost the same as preoperative. In all operated wounds healed without complications.

According to the data obtained, when using lateral access, the size of the wound is smaller than after median laparotomy $(\mathrm{P}<0,05)$. This is obviously due to the fact that in the case of surgery through the lateral abdominal wall, the increase in the size of the wound does not affect the operation, while in the case of ventral access, it greatly facilitates the operation. Similar results are reported in the literature (McGrath et al., 2004; Reece et al., 2012; Arunkumar et al., 2017).

Comparing the conditions of surgical reception with different accesses, we can note that they are favorable. Regarding the easier detection of ovaries and uterus with lateral access compared to the median, we can note that after lateral laparotomy and displacement of the omentum, the uterus is under incision, while after ventral laparotomy it is covered by the intestine. This is also reported by McGrath et al., 2004; Arunkumar et al., 2017 and Ferreira et al., 2015.

Favorable conditions for the imposition of ligatures on the ovarian ligaments and uterus when operating through the lateral abdominal wall, in our opinion, are associated with the convenient location of our proposed surgical access. However, the amount of suture material that was used in this case was almost the same and did not depend on the location of the laparotomy.

According to our data, significantly more surgical sutures were used to close the abdominal wall wound in the case of ventral access than in the case of lateral access $(\mathrm{P}<0.01)$. This is obviously due to the fact that when operating through the lateral abdominal wall to close a smaller wound, several nodal stitches were applied sepa- rately to the inner and outer oblique abdominal muscles, while in the case of median access, a furrier suture was applied to white line. In addition, the larger skin wound also required more nodular stitches to close it. Similar results were obtained by other researchers who performed ovariohysterectomy through the lateral abdominal wall (Vandana, 2005; Acharya et al., 2016).

However, it should be noted that the course and duration of the operation is influenced by such indicators as the qualification and experience of the doctor, his personal preferences in the use of a particular surgical technique.

According to our data, the location of the wound on the lateral or ventral abdominal wall creates favorable conditions for its healing. In the case of lateral access, the animal in the first days after surgery, while lying down, has less opportunity to damage the wound from the outside. Inside, the pressure of the internal organs on the lateral abdominal wall is also less.

According to McGrath et al., 2004, prolapse of the internal organs of the abdominal cavity or other severe complications due to the opening of the surgical wound are less common with lateral access, because the gravitational forces acting on the lateral incision are less than those exerted on the median wound. The location of the obliques in the lateral abdominal wall also helps maintain the integrity of the body wall in the event of early complications.

In addition, the lateral access provides opportunities for inspection of the wound and its surface treatment without excessive fixation of the animal. Similar findings were made by other researchers who operated through the lateral abdominal wall (McGrath et al., 2004; Acharya et al., 2016).

Thus, as studies have shown, when comparing the two methods of performing ovariohysterectomy in bitches, a significant difference in the duration of the operation, as well as the period of wound healing was not detected. However, it is noted that each of them has certain features.

According to the data obtained, it is relatively more difficult to perform a laparotomy and suture the wound of the abdominal wall during ovariohysterectomy with access through the white line of the abdomen.

It was also found that with a smaller $\mathrm{w}$ ound size $(\mathrm{P}<0.05)$, operative access in the upper third of the right lateral abdominal wall at the border between the iliac and groin provides favorable opportunities for ligatures on the ovarian ligaments and uterus, as well as suturing the surgical wound. The length of surgical sutures used to close the wound of the abdominal wall is probably less than when operating through the white line of the abdomen $(\mathrm{P}<0,01)$.

The obtained data make it possible to recommend the proposed right-hand access at the border of the groin and ileum when performing ovariohysterectomy in bitches as an alternative to the traditional median.

\section{Conclusions}

Surgical access for ovariohysterectomy in bitches through the right lateral abdominal wall, with an incision 
in its upper third in the direction from the anterior edge of the macula to the fourth nipple of the corresponding side of the breast is proposed.

When comparing the two methods of performing ovariohysterectomy in bitches through the ventral and lateral abdominal wall, no significant difference was found in the duration of the operation and the period of wound healing.

In ovariohysterectomy in bitches, operative access with an incision in the upper third of the right lateral abdominal wall in the direction from the anterior edge of the macula to the fourth nipple of the corresponding side of the breast provides favorable opportunities for surgery and closure of the abdominal wall.

In ovariohysterectomy in bitches, operative access through the upper third of the right lateral abdominal wall with an incision in the direction from the anterior edge of the macula to the fourth nipple of the corresponding side of the breast may be recommended as an alternative access through the white line of the abdomen.

\section{References}

Acharya, M., Sah, K. M., Singh, K. D., Singh, S., \& Dhakal, S. (2016). Comparative advantage of keyhole right flank laparotomy and ventral midline celiotomy for ovariohysterectomy in bitches. Int. J. Appl Sci Biotechnol, 4(2), 198-202. doi: 10.3126/ijasbt.v4i2.15098.

Arunkumar, S., Dilipkumar, D., Shivaprakash, B. V., \& Bhagvantappa (2017). Comparison of right flank and ventral midline approach for ovariohysterectomy in dogs. Journal of Entomology and Zoology Studies, 5(6), 2411-2416.

Bencharif, D., Amirat, L., Garand, A., \& Tainturier, D. (2010). Ovariohysterectomy in the Bitch. Hindawi Publishing Corporation Obstetrics and Gynecology International, 2010. Article ID 542693. doi: 10.1155/2010/542693.

Bierbrier, L., \& Causanschi, H. (2018). Orchiectomy and Ovariohysterectomy. In: Field Manual for Small Animal Medicine Book Ed.: Polak, K., Kommedal, A., 201-228. doi: 10.1002/9781119380528.ch9a.

Bushby, P., \& White, S. (2019). Dog Spay/Cat Spay. In book: High-Quality, High-Volume Spay and Neuter and Other Shelter Surgeries, 239-265. doi: 10.1002/9781119646006.ch12.

DeTora, M. D., \& McCarthy R. J. (2011). Ovariohysterectomy versus ovariectomy for elective sterilization of female dogs and cats: is removal of the uterus necessary? American Veterinary Medical Association (AVMA) in Journal of the American Veterinary Medical Association, 239(11), 1409-1412. doi: 10.2460/javma.239.11.1409.

Evans, H. E., \& De Lahunta, A. (2013). The Urogenital System. In H. E. Evans \& A. De Lahunta (Eds.), Miller's Anatomy of the Dog. St. Louis: Elsevier/Saunders, 361-406.

Ferreira, A. R. A., Silva, W. M., Souza, M. R., \& Costa Neto J. M. (2015). Comparação entre as abordagens lateral direita e mediana ventral em cadelas submetidas à ovariossalpingohisterectomia. Arq. Bras. Med. Vet. Zootec., 67(4). doi: 10.1590/1678-4162-7500.

Freeman, A., \& MacFarlane P. (2007). Laparoscopic ovariohysterectomy in dogs. Journal Article published in Veterinary Record, 160(23), 812. doi: 10.1136/vr.160.23.812-a.

Howe, L. M. (2006). Surgical methods of contraception and sterilization. Theriogenology, 66(3), 500-509. doi: 10.1016/j.theriogenology.2006.04.005.

Kutzler, M., \& Wood, A. (2006). Non-surgical methods of contraception and sterilization. Theriogenology, 66(3), 514-525. doi: 10.1016/j.theriogenology.2006.04.014.

McGrath, H., Hardie, R. J., \& Davis, E. (2004). Lateral flank approach for ovariohysterectomy in small animals. Compend. Contin. Educ. Small. Anim. Pract, 26, 922-930. https://vetfolio-vetstreet.s3.amazonaws. com/mmah/09/4b8f4bfa764cc9b20481c797956733/fil ePV_26_12_922.pdf.

Murai, A., Nishii, N., Morita, T., \& Yuki, M. (2012). GHproducing mammary tumors in two dogs with acromegaly. J Vet Med Sci, 74(6), 771-774. doi: 10.1292/jvms.11-0361.

Nakamura, K., Yamasaki, M., Osaki, T., Hiroshi, O., \& Sasaki, N. (2012). Bilateral segmental aplasia with unilateral uterine horn torsion in a Pomeranian bitch. Journal of the American Animal Hospital Association, 48(5), 327-330. doi: 10.5326/JAAHA-MS-5771.

Pöppl, A. G. Mottin, T. S., \& González F. H. D. (2013). Diabetes mellitus remission after resolution of inflammatory and progesterone-related conditions in bitches. Res Vet Sci, 94(3), 471-473. doi: 10.1016/j.rvsc.2012.10.008.

Quessada, A. M., Sousa, A. A. R., Costa, A. P. R., de Sousa, S., Costa A. A., \& Rocha, R. R. (2009). Comparação de técnicas de ovariosalpingohisterectomia em cadelas. Acta Scientiae Veterinariae, 37(3), 253258. doi: 10.22456/1679-9216.16341.

Reece, J. F., Nimesh, M. K. Wyllie, R. E. Jones, A. K., \& Dennison, A. W. (2012). Description and evaluation of a right flank, mini-laparotomy approach to canine ovariohysterectomy. Veterinary Record, 171(10), 248. doi: 10.1136/vr.100907.

Rhindali, L., Biggeri, A., Carbone, S., Musella, V., Catelan, D., Veneziano, V., \& Cringoli, G. (2006). Canine fecal contamination and parasitic risk in the city of Naples (Southern Italy). BMC Vet Res, 2, 2935. doi: 10.1186/1746-6148-2-29.

Smith, T. J., \& Séguin, B. (2012). Ovariectomy and Ovariohysterectomy. In: Eric Monnet Small Animal Surgery. doi: 10.1002/9781118997505.ch63.

Vandana, S. (2005). Right flank ovariohysterectomy in dogs. Indian Veterinary Journal, 82, 1118-1119.

Zanzani, S. A., Di Cerbo, A. R., Gazzonis, A. L., Genchi, M., Rinaldi, L., Musella, V., Cringoli, G., \& Manfredi, M. T. (2014). Canine Fecal Contamination in a Metropolitan Area (Milan, North-Western Italy): Prevalence of Intestinal Parasites. The Scientific World Journal, 2014, 1-6. doi: 10.1155/2014/132361. 